\title{
Perception of invulnerability, engaging in risky behaviors and life satisfaction among high school students
}

\author{
Marija Milić \\ Department of Psychology, Faculty of Humanities and Social Sciences, \\ Josip Juraj Strossmayer University of Osijek \\ $\square$ E-mail:mmilic@ffos.hr \\ Ružica-Marija Vlajčić \\ Valerija Križanić \\ Department of Psychology, Faculty of Humanities and Social Sciences, \\ Josip Juraj Strossmayer University of Osijek
}

\begin{abstract}
A sense of invulnerability is commonly associated only with adolescents' risk behaviors, but according to some developmental theories, it is also an adaptive response to developmental tasks that occur during that period of life. The objective of this paper was to explore two aspects of the sense of invulnerability (physical and psychological) on a sample of high school students. More specifically, the relationship between physical and psychological invulnerability in terms of engagement in risky behaviors (cigarette use) on the one hand and indicators of subjective wellbeing (life satisfaction) on the other was explored. The data from 297 adolescents aged 16 to 20 years ( $M=17.33 ;$ SD $=0.834 ; 54.2 \%$ girls) were analyzed. The study found that boys' assessment of physical and psychological invulnerability was higher in comparison to girls' assessment. Smokers rated their physical invulnerability higher than adolescents who had quit smoking, who had only tried smoking and those who had never smoked. While physical invulnerability was not associated with life assessments in most domains of life satisfaction, psychological was positively associated with all domains as well as general life satisfaction. The findings also showed that assessing psychological invulnerability contributed more to explaining life satisfaction than assessing physical invulnerability, whereas physical invulnerability was a significant predictor of smoking frequency among adolescents. The results of this study indicate the significance and importance of both domains of invulnerability in adolescence.
\end{abstract}

Key words: adolescents, physical and psychological invulnerability, smoking, life satisfaction

\section{Introduction}

Adolescence is characterized by significant changes in terms of how young people function and therefore brings about a number of new challenges for appropriate adjustment. On the other hand, adolescents are more likely to engage in risky behavior compared to other age groups (Steinberg, 2008). This period is marked by sharp increase in risky behaviors that might be health-compromising (Arnett, 1992), including alcohol and tobacco consumption, substance abuse, unprotected sexual activity etc. (Zloković and Vrcelj, 2010). Although the consequences of these types of behavior may vary and some might be perceived by adolescents as desirable (e.g. 
perceived popularity among peers, seduction of a partner) the society is worried about their potential negative effects in terms of life-threatening activities (accidents and other adverse events connected to these behaviors) and adolescents' health (Trimpop, 1994).

This paper focuses on smoking among young people that represents one of the types of risky behaviors that puts in danger smokers' own health and health of others around them. On the one hand, smoking is the single most preventable risk factor for many chronic diseases. On the other hand, cigarette smoking has been recognized as one of the leading causes of illness in Croatia and the risk remains extremely high among youngsters who start smoking before the age of 15 (according to the Croatian Institute of Public Health, [CIPH], 2016). Analysis of trends in terms of tendency of young people to engage in health risk behaviors on the basis of the data from the international survey carried out in 2015, showed that cigarette smoking had assumed alarming proportions in Croatia (CIPH, 2016). Some $62 \%$ of (first and second year) high school students said they had smoked on one or several occasions, whereas $23 \%$ said they had smoked in the last 30 days. The same percentage of respondents said they smoked on a daily basis. The comparison of these data with those collected 20 years ago shows that, on average, the share of high school students who smoked decreased in the analysed countries, whereas, in the case of Croatia, their share rose by $1 \%(\mathrm{CIPH}, 2016)$.

Given the potentially adverse consequences of these types of behavior for young people and people around them, as well as the study findings that point to potential correlation between smoking and other, more serious, behavioral problems (Ellickson, Tucker and Klein, 2001), deeper insight into this phenomenon (risk-taking behavior) might be needed. Research-based insights on key mechanisms behind these types of behavior among the youth are an important link in forming more effective social interventions and prevention programs. The main purpose of this paper is to contribute to the pool of scientific facts about this problem.

According to Kalebić Maglica and Martinac Dorčić (2015), reasons behind risk-taking behaviors among young people were mostly analysed by relying on two approaches: the approach that put personality traits in focus and the one that placed more emphasis on situational and wider social contextual factors. The epidemiological findings show that, among adults who have smoked at any point in their lives, $86.9 \%$ tried their first cigarette by the time they were 18 years of age (USDHHS, 2014). For this reason, it is important to identify risk factors for smoking initiation before turning 18. Research points to some factors associated with higher probability for early smoking onset among adolescents, for instance, older age (O'Loughlin, Karp, Koulis, Paradis and DiFranza, 2009), close social environment that includes smokers (parents, siblings, friends; Gilman et al., 2009), low self-esteem (Khosravi, Mohammadpoorasl, Naieni, Mahmoodi, Pouyan and AliMansournia, 2016), curiosity, social pressure (Sarason, Mankowski, Peterson and Dinh, 1992), high levels of perceived stress (Bonilha, de Souza, Sicchieri, Achcar, Crippa and Baddini-Martinez, 2013) etc. Several studies have shown that, compared to non-smokers, adolescent smokers estimated that perceived benefits of smoking outweighed the risks (Aryal, Petzold and Krettek, 2013; Halpern-Felsher, Biehl, Kropp and Rubinstein, 2004; Krosnick, Chang, Sherman, Chassin and Presson, 2006; Rodriguez, Romer and Audrain-McGovern, 2007; Romer and Jamieson, 2001; Song et al., 2009). If we analyse the increased propensity of adolescents to take risks, the accompanying literature shows that there is a widespread opinion that reasons behind these types of behavior lie in their heightened sense of 
invulnerability to danger, injury or any harm (Arnett, 1992; Hill, Dugan and Lapsley, 2012; Lapsley and Hill, 2010). From this perspective, a sense of invulnerability among adolescents may be considered a psychosocial risk factor and should thus be targeted by interventions if we want to minimize the extent to which adolescents engage in health risk behavior (Trimpop, 1994). On the other hand, research findings have not been consistent, so some authors point to adolescent tendency to engage in risk taking behavior coupled with increased sense of vulnerability (e.g. Cohn, Macfarlane, Yanez and Imai, 1995; Gerrard, Gibbons, Benthin and Hessling, 1996). In that respect, any decisions whether the sense of vulnerability should be covered by intervention or prevention programs and in what ways should be based on clear theoretical understanding of the basic function of sense of invulnerability in normal development of adolescents. Two approaches have mostly been used to explain invulnerability: cognitive and developmental approach.

According to the cognitive approach, invulnerability represents the cognitive bias that has a negative effect on the decision-making process in both adolescents and adults (Millstein and Halpern-Felsher, 2002; Weinstein and Klein, 1996). It is connected to the optimistic bias, generally defined as a certain cognitive error that induces a sense of invulnerability in the decision-making process (mostly when assessing negative and adverse future outcomes). In the process, the individual concerned compares himself/herself with others. The person believes that, if he/she engages in risky behaviors (such as smoking), he/she is more likely to enjoy the benefits, rather than experience negative effects, compared to other people. This type of bias may have adverse effects on the individual and his/her wellbeing because he/she overestimates positive and underestimates negative consequences (e.g. developing cancer) and thus does not have any particular motivation to become involved in accompanying protective behaviors.

The developmental approach to invulnerability includes two lines of thinking. According to the first, invulnerability is an effect of one type of cognitive error that occurs in formal operational stage (12 years of age), the so-called differentiation error (Elkind, 1967). It takes form in poor differentiation between universal and unique categories. For instance, adolescents may think that people who smoke for over 40 years develop cancer (universal outcome), but, at the same time, they are convinced that this does not apply to them in the same situation (i.e. if they smoked for over 40 years - unique outcome). In other words, differentiation error occurs as a belief that universal principles and their effects apply to all risky behaviors, but not to us. The Elkind theory of adolescent egocentrism (1967) backs this approach. The theory assumes that an adolescent perceives his/her experience and events as unique and special and therefore may not be comprehended by others because they are bound by universal outcomes.

The other line of thinking perceives invulnerability as an adaptive response to the separation-individuation process in a young person's development. The process is marked by a child's diminishing dependence on parents and gradual development of its own identity, values and beliefs to form an independent individual. According to this approach, invulnerability does not amount to differentiation error, but represents an adaptive response to developmental challenges inherent in the separation-individuation process (Lapsley, Fitzgerald, Rice and Jackson, 1989). The sense of invulnerability does not result from an error in cognitive development, but development of the ego. Although both these developmental approaches include the thesis that invulnerability stems from a normative (regular) developmental process within an individual, they do differ in terms of 
assumed implications of the sense of invulnerability for adaptive functioning. Apart from stating that the sense of invulnerability predicts risky behaviors, this approach presupposes and predicts positive outcomes for individual wellbeing, i.e. individual's adjustment, coping with stress and stress resilience (Aalsma, Lapsley and Flannery, 2006). It assumes that a certain degree of sense of invulnerability may strengthen adolescents in their developmental period when facing new developmental challenges. Establishing their identity, making friendships, learning new skills, entering into romantic relationships - these activities require inclination to deal with new situations with an unknown outcome or propensity to take certain risks. Risk taking may result in more successful coping with new situations and developmental challenges. At times, quite the opposite is true. On the other hand, even feelings of failure prepare adolescents to take on challenges ahead of them when entering adulthood (Lapsley and Hill, 2010). In short, this perspective puts emphasis on potentially adaptive functions of sense of invulnerability.

Empirical findings have shown that invulnerability in adolescents, on the one hand, predicts a number of risky behaviors, but also certain positive developmental outcomes (e.g. self-esteem, problem-focused coping, indicators of good adjustment; according to Lapsley, 2003). These different theoretical perspectives and diverging empirical findings have encouraged researchers to revisit the assumption about invulnerability as a one-dimensional construct with simple (and purely negative) implications. According to Lapsley (2003), these findings point to two faces of invulnerability. One represents a risk factor for health-compromising behavior; the second is associated with positive aspects of adolescent mental health. Potential theoretical integration of these two faces of invulnerability stems from the idea that they should be conceptualized as two different dimensions of the same phenomenon and thus treated as special constructs.

From theoretical and logical point of view, it makes sense to differentiate between the sense or perception of one's own vulnerability in terms of potential threats or physical force and the perception of the same condition in terms of "subjective" threats (threats that stem from subjective evaluation of a certain event for the individual concerned). The key difference lies in the fact that, in the first case, unrealistic assessment may increase the propensity to engage in compromising behaviors, especially in terms of physical wellbeing. In the second instance, biased assessment may represent personal psychological resources, even "positive illusions" associated with a number of criteria of positive aspects of mental health. According to Taylor and Gollwitzer (1995), some of the criteria include positive self regard, the capacity for productive and creative work, the ability to care for and about other people and the ability to manage stress effectively.

There are very few instruments that conceptualize invulnerability in such a comprehensive way. Yet, by taking into account the above-mentioned developmental approach that treats invulnerability as a potential adaptive mechanism, Lapsley and Hill (2010) have developed the Adolescent Invulnerability Scale (AIS) comprised of two subscales: a) danger invulnerability (hereinafter: physical invulnerability) refers to the individual's sense of personal indestructibility in the face of physical risks; and b) psychological invulnerability that covers the extent to which an individual feels undaunted by psychological or personal distress. This is one of the most widely used instruments when analysing invulnerability in adolescents. 
Marija Milić, Ružica-Marija Vlajčić, Valerija Križanić: Perception of invulnerability, engaging in...

According to the developmental approach of interpreting invulnerability, this perception should first appear in early adolescence (Hill, Duggan and Lapsley, 2012). Yet, not much empirical research has been conducted to examine these assumptions. Morrell, Lapsley and Helpern-Felsher (2016) found rise in psychological invulnerability in 14-year old respondents in six-month period. At the same time, statistically significant increase was not observed in terms of physical invulnerability. Studies that measure invulnerability as a one-dimensional construct point to higher invulnerability in early and middle adolescence. Aalsma, Lapsley and Flannery (2006), as well as Alberts, Elkind and Ginsberg (2007) found that invulnerability among students in middle adolescence peaked compared to those in its early stage (although these groups of authors had used different instruments when measuring sense of invulnerability). Millstein and Halpern-Felsher (2002) state that very few studies comparing adolescents and adults in terms of invulnerability were conducted and that those that were gave conflicting results. The authors found that, compared to adolescents, emerging adults had heightened perception of invulnerability, but emphasised that its development during adolescence and adulthood had not been examined enough.

Unlike age differences, differences between sexes have emerged more in studies on invulnerability. Boys thought they were more physically and psychologically invulnerable compared to girls (Lapsley and Hill, 2010). It is interesting to note that sexes did not differ in terms of optimism bias, yet differences emerged when it came to physical and psychological invulnerability. These findings support the thesis that invulnerability and biased optimism represent two different constructs (Lapsley and Hill, 2010). Subjective invulnerability has adaptive functions in adjustment of young people to challenges in their social and psychological transitions during the coming of age stage. If this is the case, it may account for the fact that, invulnerability helps boys to cope with stress that may appear in this age period more effectively than it does to girls (Lapsley and Hill, 2010).

Boys perceived themselves as more successful in managing stress than girls. Roothman, Kirsten and Wissing (2003) think that this is due to implicit and conventional beliefs about masculinity and femininity. Masculine characteristics include competitiveness, fearlessness, invulnerability (Good, Sherrod and Dillon, 2000), which are all traits of an individualistic identity (Nolen-Hoeksema and Rusting, 1999). Young men thus use these capacities when dealing with stress and stressful situations. It is therefore expected that men will rate themselves high in terms of these masculine traits to prevent internal conflict with their gender role (Roothman et al., 2003). Unlike men, women are more focused on interpersonal relations and spirituality (Roothman i sur., 2003). They did not perceive invulnerability as important for self-assessment and confirmation of their identity.

By using the AIS (Adolescent Invulnerability Scale), Lapsley and Hill (2010) examined hypotheses on two types of invulnerability, i.e. the differences between invulnerability associated with risky behaviors (physical invulnerability) and the invulnerability characteristic of behaviors connected to successful adjustment (psychological invulnerability). The survey was carried out on a sample of emerging (young) adults. The results on both scales showed positive correlation between risky behavior and substance abuse. Compared to psychological invulnerability, greater correlation was observed for physical invulnerability and these behaviors. On the other hand, respondents who reported higher degree of psychological invulnerability had fewer problems with self-esteem, depression and interpersonal issues. Positive correlation was established between physical invulnerability and interpersonal problems only. Physical invulnerability was not positively related with 
depression-related problems and low self-esteem. Hill, Duggan and Lapsley (2012) confirmed these findings in their study involving respondents in early adolescence. Their study has confirmed that physical invulnerability positively predicted delinquency and frequency of drug use. Psychological invulnerability was positively related with positive adjustment and mastery and copying (aspects of psychological wellbeing) and it counterindicated depressive symptoms. Unlike psychological, physical invulnerability was not a significant predictive variable for the psychological wellbeing criterion. According to Hill et al. (2012), these findings go hand in hand with the thesis that a sense of invulnerability may in fact benefit adolescents because it promotes positive adjustment and identity formation.

Research trends have covered the manifest need to conceptualize health and adjustment models in a more comprehensive manner and incorporate both positive and negative indicators in them (Antaramian, Huebner and Valois, 2008). Adolescents' life satisfaction scales have been getting much attention lately (Huebner, 2004). Life satisfaction is defined as the individual evaluation of quality of life generally and/or in specific life domains (Diener, Suh, Lucas and Smith, 1999) and, as such, represents one of the aspects of a person's subjective wellbeing. Given numerous changes during adolescence, positive or negative adjustment to new goals and challenges may have significant effects on adolescents' life satisfaction. A number of studies have shown that successful achievement of developmental tasks in young people and satisfaction in specific life domains (academic achievements, romantic relationships, professional careers) is associated with better global evaluation of life satisfaction (Kriesi and Buchmann, 2012; Räikkönen, Kokko, Chen and Pulkkinen, 2012; Salmela-Aro, Ek, Taanila and Chen, 2012; Schoon, Martin and Ross, 2012; Schulenberg, Bryant and O'Malley, 2004). In short, according to Goldbeck, Schmitz, Besier, Herschbach and Henrich (2007), life satisfaction is a relevant variable that may give us a better insight into successful coping with developmental challenges and tasks among adolescents.

Every four years, the World Health Organization (WHO) has been conducting the Health Behaviour in School-aged Children (HBSC) study to examine life satisfaction among young people aged between 11 and 15 in over 40 countries in North America and Europe (HBSC, 2016). The survey results have shown that life satisfaction tends to decrease with age for boys and girls alike, but, in general terms, boys reported higher life satisfaction levels compared to girls (HBSC, 2016). By analysing the findings of the HBSC study, Ottová-Jordan et al. (2015) found diverging tendencies in terms of life satisfaction among different countries. For instance, linear increase in life satisfaction was observed in countries such as Denmark, Finland and Norway. A U-shaped trend was observed in some countries (Austria, Canada or Scotland). Finally, cohorts of respondents reported sharp decline in life satisfaction in countries such as Greece, Croatia or Spain. The authors attribute these findings to contextual differences, such as different expectations in respondents' life environment (from family, peers, school) or particular conditions of their home country (economic situation, social (in)security, unemployment rates). These are all factors that may contribute to rising stress levels, concerns about the future and may have an impact on life satisfaction both generally and in different life domains.

Apart from being considered one of the indicators of a person's quality of life (as a personal evaluation of life outcomes, according to Veerhoven, 2000), life satisfaction is also a predictor of several other outcomes. It has been confirmed that it is a variable that represents a significant predictor 
of depression disorders and suicidal ideation among adolescents (Hawkins, Hawkins and Seeley, 1992; Park, Hoo and Schepp, 2005). According to findings of earlier studies, global life satisfaction scales turned out to be predictors of substance abuse (Newcomb, Bentler and Collins, 1986; Zullig, Valois, Hubner, Oeltmann and Drane, 2001), suicide (Koivumaa-Honkanen, Honkanen, Viinamaki, Heikkila, Kaprio and Koskenvuo, 2001), as well as deaths due to fatal injuries (Koivumaa-Honkanen, Honkanen, Koskenvuo, Viinamaki and Kaprio, 2002). Correlational research does not allow us to draw decisive conclusions whether life dissatisfaction represents a determinant of behaviors such as substance abuse or consequence of this type of health risk behavior (e.g. Zullig at al., 2001). On the other hand, longitudinal studies have emphasised the importance of life satisfaction studies among adolescents. They have found that a low life satisfaction level predicts subsequent externalizing and internalizing behavior problems and peer relational victimization (Haranin, Huebner and Suldo, 2007; Martin, Huebner and Valois, 2008) and that adolescents who were extremely satisfied with their lives were less likely to have externalizing behavior problems after subsequent stress in life (Suldo and Huebner, 2004). By taking into account these findings, according to Antaramian et al. (2008), life satisfaction may be perceived as an empowering factor that can facilitate one's adjustment to new goals and situations in emerging adulthood.

Despite interpretations of invulnerability in the context of adolescents' behavior, the research community has not yet reached a consensus about the construct of the sense of invulnerability or, indeed, its implications for adolescence (Aalsma, Lapsley and Flannery, 2006; Lapsley and Hill, 2010). In that sense, the following paper tries to give its contribution to better insight into this topic by exploring the "dual nature" of sense of invulnerability. The existing empirical evidence of the invulnerability concept established in this way was based on the findings of the adolescent invulnerability scale (AIS) (Lapsley and Hill, 2010) so the analysis of this construct by using other similar instruments may serve as the confirmation of its basis. If other instruments (used in the present study) help us to find different patterns of connection between physical and psychological invulnerability on the one hand and various behaviors and evaluations of life satisfaction on the other, the study will give its own contribution to the thesis about the "dual nature" of invulnerability. Furthermore, the paper tries to add to the existing findings about feelings of physical invulnerability and engagement in health risk behaviors of adolescents. In the process, we will analyse whether feelings of invulnerability may contribute to better understanding of qualitative differences among adolescents in terms of risk taking behaviors and differences in the frequency (intensity) of these behaviors. Finally, the paper proposes a thesis that invulnerability represents more than a result of a cognitive error but also includes more complex systems in its basis that provide psychological protection and/or empower individuals in behaviors that are useful for achieving his/her psychosocial goals typical of adolescent age (and his/her preparation for adulthood). This thesis is analysed by introducing indicators of positive aspects of adjustment (satisfaction with life and different life domains) and analysis of their relation to a sense of invulnerability. This research also contributes to the examination of the relation between psychological invulnerability and one of the aspects of subjective wellbeing (life satisfaction), since, in the majority of cases, the existing research associated psychological invulnerability with psychological wellbeing (e.g. self-esteem, interpersonal relations; Duggan and Lapsley, 2012; Lapsley and Hill, 2010). 


\section{Objective, research problems and hypotheses}

In line with the above-mentioned theses, the objective of this paper is to examine two aspects of sense of invulnerability (physical and psychological) on a sample of high school students and the relationship between those two aspects and engagement in risky behaviors on the one hand and indicators of subjective wellbeing on the other.

There are several more specific research problems involved. The first one is to examine the relation between perception of physical and psychological invulnerability and age, sex and satisfaction with specific domains of life. It is expected that older respondents and boys would report higher levels of physical and psychological invulnerability compared to younger students and girls. If we rely on the thesis that physical and psychological invulnerability represented connected, yet different, constructs, we expect different patterns of connection to the satisfaction scales with specific domains of life.

The second one is to examine how perception of physical and psychological invulnerability contributed to frequency of cigarette smoking among high school students and their life satisfaction in general. Since physical invulnerability is more frequently associated with risky behavior (and psychological invulnerability with more positive developmental aspects of emerging adulthood), physical invulnerability is expected to be a more pronounced predictor of frequency of smoking. By the same token, psychological invulnerability should be a better predictor of general life satisfaction.

The third problem concerns differences regarding the sense of invulnerability among high school students with different qualitative experience in risk taking behavior of cigarette use. If we assume that physical invulnerability represents a risk factor for smoking initiation, it is expected that high school students who never tried smoking would perceive lowest physical invulnerability, unlike experimental (somewhat higher sense of invulnerability) and regular (greatest physical invulnerability) smokers. By interpreting psychological invulnerability as a potential personal recourse that helps an individual to manage stress or resist social pressure (some of the reasons for smoking initiation), we expect it to be at highest levels among students who never engaged in this type of behavior compared to the other groups.

\section{Method}

\section{Respondents}

The paper analyses the data of $N=297$ students ( $n=161$ girls) of the second (29.1\%), third (43.58\%) and fourth (34.3\%) year of high school. The students were recruited from different high schools located across Slavonia. The research involved students of the Osijek Medical School $(n=73)$, Đakovo Grammar School $n=88$ ) and students of three and four-year programs of the Đakovo Vocational School $(n=136)$. The respondents were within the $16-20$ age group $(M=17.33$; $S D=0.834)$. A total of $26.9 \%$ never tried smoking. A similar percentage (24.9\%) tried smoking but were not smokers, whereas $7.1 \%$ had smoked but quit and $41.1 \%$ reported they smoked occasionally or regularly. 


\section{Instruments}

The Invulnerability Scale (Ćorić, Vlajčić, Goretić i Kolak, 2018) was employed to evaluate how invulnerable the respondents felt. The scale included 30 items divided into two subscales, namely: physical invulnerability (17 items) and psychological invulnerability (13 items). A 4-level Likert-type scale was used for responses, whereby $1=$ "I strongly disagree" and $4=$ "I strongly agree". The total of both subscales formed the mean value of evaluations for all items. The results ranged between 1 and 4 whereby higher result equalled higher perception of (psychological or physical) invulnerability. Examples of items of physical invulnerability were: "I could use psychoactive substances (drugs, alcohol, nicotine) without any long-term consequences", "I can get drunk without anything bad happening to $m e^{\prime \prime}$, whereas the examples of psychological invulnerability included: "Peer teasing doesn't bother me" "I 'm afraid I won't achieve everything I want to achieve". Five items on the physical invulnerability scale and three on the psychological invulnerability were reversely coded. A good value of Cronbach's alpha internal consistency coefficient was found (.82 for physical invulnerability scale and .75 for psychological invulnerability scale).

The Personal Wellbeing Index-Adult (PWI-A) (International Wellbeing Group, 2013) is one of the most frequently used scales for measuring life satisfaction (Kovčo Vukadin, Novak and Križan, 2016). The PWI-A measures satisfaction with the following seven life domains: standard of living, health, life achievements, personal relationships (family and friends), personal safety, community connectedness and future security. It also contains a question on general life satisfaction. Each domain and general life satisfaction was measured by using one item. The questionnaire thus included a total of eight items. The responses on the scale were rated according to the 11-level Likert-type scale, whereby $0=$ "completely dissatisfied" and $10=$ "completely satisfied".

Cigarette use was covered in two questions. The first question: "Which of the following statements best applies to you?" relates to the general prevalence of cigarette use (Fidler, Wardle, Henning Broderson, Jarvis and West, 2006). Respondents were asked to select one of the statements provided: whether they smoked over six cigarettes a week; one to six a week; whether they smoked occasionally but no more than one cigarette a week; whether they had smoked before, but quit; whether they tried smoking once only or never smoked. This question was included to differentiate groups of respondents with qualitatively different experience in terms of engagement in this type of risky behavior. Based on the responses, four groups of respondents were identified: 1) "never tried smoking"; 2) "tried smoking but do not smoke"; 3) "quit smoking" and 4) "smoking" (in cases where any of the first three statements was selected). The second question: "How often do you use cigarettes?" (Kalebić-Maglica and Dorčić, 2015) included a 5-level scale ( $1=$ never; $5=$ every day) whereby a higher score pointed to more frequent cigarette use. In the research, the variable formed on the basis of the second question was later used as a criterion variable in the statistical analysis of the second research problem. The reference was made to the approach adopted in the above-mentioned work (Kalebić-Maglica and Dorčić, 2015).

\section{Procedure}

The research was approved by the Ethical Committee of the Faculty of Humanities and Sciences in Osijek. The survey was carried out in groups, either at the beginning or the end of a 
lesson. The filling in procedure took some 20 minutes. Students were explained the purpose of the survey. They were told it was anonymous and voluntary so they could withdraw from the procedure at any point. In addition, they were explained that the results would be used for research purposes only and that they would be processed at a group level.

Once the respondents filled in the questionnaires, the surveyors thanked them for their cooperation. Respondents were distributed leaflets explaining harmful effects of smoking.

\section{Results}

Before we go through the statistical analysis of research problems, it is noteworthy to refer to the Table 1 illustrating descriptive indicators for quantitative variables included in the subsequent analyses.

Table 1. Descriptive statistical analysis of the main research variables $(N=297)$

\begin{tabular}{|l|c|c|c|c|c|c|}
\cline { 2 - 7 } \multicolumn{1}{c|}{} & $\mathbf{M}$ & $\mathbf{S D}$ & $\begin{array}{c}\text { Observed } \\
\text { minimum }\end{array}$ & $\begin{array}{c}\text { Observed } \\
\text { maximum }\end{array}$ & $\begin{array}{c}\text { Theoretical } \\
\text { minimum }\end{array}$ & $\begin{array}{c}\text { Theoretical } \\
\text { maximum }\end{array}$ \\
\hline Physical invulnerability & 2.12 & 0.545 & 1.06 & 3.81 & 1.00 & 4.00 \\
\hline Psychological invulnerability & 2.75 & 0.474 & 1.38 & 4.00 & 1.00 & 4.00 \\
\hline Smoking & 2.35 & 1.648 & 1 & 5 & 1 & 5 \\
\hline General life satisfaction & 7.48 & 2.296 & 0 & 10 & 0 & 10 \\
\hline Satisfaction with: & & & & & & 10 \\
\hline - standard of living & 7.99 & 1.936 & 0 & 10 & 0 & 10 \\
\hline - health & 8.08 & 2.003 & 0 & 10 & 0 & 10 \\
\hline - life achievements & 7.51 & 2.070 & 0 & 10 & 0 & 10 \\
\hline - personal relationships & 8.22 & 2.159 & 0 & 10 & 0 & 10 \\
\hline - personal safety & 8.24 & 2.038 & 0 & 10 & 0 & 10 \\
\hline - community connectedness & 7.77 & 2.405 & 0 & 10 & 0 & 10 \\
\hline - future security & 7.21 & 2.438 & 0 & 10 & 0 & 10 \\
\hline
\end{tabular}

Notes: M — arithmetic mean; SD — standard deviation; a the "smoking" variable covers responses to the question: "How often do you use cigarettes?"

To examine connection between the analysed variables analysed in the research, we have calculated correlation coefficients between them. 
Marija Milić, Ružica-Marija Vlajčić, Valerija Križanić: Perception of invulnerability, engaging in...

Table 2. Correlation of variables included in research problems $(N=297)$

\begin{tabular}{|c|c|c|c|c|c|c|}
\hline & Sex & $\begin{array}{c}\text { Physical } \\
\text { invulnerability }\end{array}$ & $\begin{array}{l}\text { Psychological } \\
\text { invulnerability }\end{array}$ & Smoking & $\begin{array}{l}\text { General life } \\
\text { satisfaction }\end{array}$ & $\begin{array}{l}\text { Satisfaction } \\
\text { with } \\
\text { standard of } \\
\text { living }\end{array}$ \\
\hline Age & $-.20^{\star *}$ & $.22^{* *}$ & $.17^{* *}$ & $.21^{* *}$ & .06 & -.03 \\
\hline Sex & & $-.43^{\star \star}$ & $-.30^{\star *}$ & -.06 & -.09 & -.10 \\
\hline $\begin{array}{c}\text { Physical } \\
\text { invulnerability }\end{array}$ & & & $.42^{* *}$ & $.45^{* *}$ & -.05 & -.04 \\
\hline $\begin{array}{l}\text { Psychological } \\
\text { invulnerability }\end{array}$ & & & & $.15^{* *}$ & $.32^{\star *}$ & $.32^{* \star}$ \\
\hline Smoking & & & & & -.06 & -.01 \\
\hline $\begin{array}{l}\text { General life } \\
\text { satisfaction }\end{array}$ & & & & & & $.62^{* *}$ \\
\hline \multicolumn{7}{|l|}{$\begin{array}{l}\text { Satisfaction with } \\
\text { standard of living }\end{array}$} \\
\hline \multicolumn{7}{|l|}{$\begin{array}{l}\text { Satisfaction with } \\
\text { health }\end{array}$} \\
\hline \multicolumn{7}{|l|}{$\begin{array}{l}\text { Satisfaction with } \\
\text { life achievements }\end{array}$} \\
\hline \multicolumn{7}{|l|}{$\begin{array}{l}\text { Satisfaction } \\
\text { with personal } \\
\text { relationships }\end{array}$} \\
\hline \multicolumn{7}{|l|}{$\begin{array}{l}\text { Satisfaction with } \\
\text { personal safety }\end{array}$} \\
\hline $\begin{array}{l}\text { Satisfaction with } \\
\text { community } \\
\text { connectedness }\end{array}$ & & & & & & \\
\hline
\end{tabular}


Criminology \& Social Integration Vol 27 (2019) 2, $177-203$.

\begin{tabular}{|c|c|c|c|c|c|c|}
\hline & $\begin{array}{l}\text { Satisfaction } \\
\text { with health }\end{array}$ & $\begin{array}{l}\text { Satisfaction with } \\
\text { life achievements }\end{array}$ & $\begin{array}{l}\text { Satisfaction } \\
\text { with personal } \\
\text { relationships }\end{array}$ & $\begin{array}{c}\text { Satisfaction } \\
\text { with personal } \\
\text { safety }\end{array}$ & $\begin{array}{l}\text { Satisfaction } \\
\text { with } \\
\text { community } \\
\text { connectedness }\end{array}$ & $\begin{array}{c}\text { Satisfaction } \\
\text { with future } \\
\text { security }\end{array}$ \\
\hline Age & -.11 & $.13^{*}$ & .05 & $.17^{\star \star}$ & .07 & .08 \\
\hline Sex & -.11 & $-.18^{\star \star}$ & -.04 & $-.16^{\star \star}$ & -.03 & $-.24^{\star *}$ \\
\hline $\begin{array}{c}\text { Physical } \\
\text { invulnerability }\end{array}$ & $-.12^{*}$ & .03 & -.09 & .04 & -.02 & $.12^{*}$ \\
\hline $\begin{array}{l}\text { Psychological } \\
\text { invulnerability }\end{array}$ & $.23^{* *}$ & $.45^{\star \star}$ & $.24^{\star *}$ & $.35^{\star \star}$ & $.22^{\star \star}$ & $.48^{\star \star}$ \\
\hline Smoking & $-.20^{\star *}$ & -.06 & -.03 & -.04 & -.01 & .02 \\
\hline $\begin{array}{l}\text { General life } \\
\text { satisfaction }\end{array}$ & $.38^{\star \star}$ & $.70^{* *}$ & $.56^{\star *}$ & $.50^{\star *}$ & $.57^{\star \star}$ & $.56^{\star *}$ \\
\hline $\begin{array}{l}\text { Satisfaction with } \\
\text { standard of living }\end{array}$ & $.30^{\star *}$ & $.46^{\star *}$ & $.46^{\star \star}$ & $.39^{\star *}$ & $.43^{\star \star}$ & $.42^{* \star}$ \\
\hline $\begin{array}{l}\text { Satisfaction with } \\
\text { health }\end{array}$ & & $.35^{\star *}$ & $.22^{\star \star}$ & $.39^{* *}$ & $.28^{\star \star}$ & $.34^{\star \star}$ \\
\hline $\begin{array}{l}\text { Satisfaction with } \\
\text { life achievements }\end{array}$ & & & $.51^{* *}$ & $.47^{\star \star}$ & $.50^{\star \star}$ & $.57^{\star \star}$ \\
\hline $\begin{array}{l}\text { Satisfaction } \\
\text { with personal } \\
\text { relationships }\end{array}$ & & & & $.45^{\star \star}$ & $.51^{\star \star}$ & $.40^{\star \star}$ \\
\hline $\begin{array}{l}\text { Satisfaction with } \\
\text { personal safety }\end{array}$ & & & & & $.52^{\star *}$ & $.51^{\star \star}$ \\
\hline $\begin{array}{l}\text { Satisfaction with } \\
\text { community } \\
\text { connectedness }\end{array}$ & & & & & & $.44^{\star \star}$ \\
\hline
\end{tabular}

Notes: a The "smoking" variable covers responses to the question "How often do you use cigarettes?"

${ }^{*} p<.05$; ${ }^{* *} p<.01$; the "sex" variable was coded in the following way: $1=$ boys, $2=$ girls 
Marija Milić, Ružica-Marija Vlajčić, Valerija Križanić: Perception of invulnerability, engaging in...

As the Table 2 demonstrates, moderation connection was found between physical and psychological invulnerability. This should not come as a surprise because they measure two relatively close constructs, i.e. perception of two aspects of a person's invulnerability. Although it was found, the correlation was not significant to the degree that it might exclude these variables taken together in subsequent analyses. For instance, according to Field (2015), predictors in regression analysis should not be included in the analysis together if the correlation coefficient obtains power of .80 or greater. Also, the Table 2 illustrates positive relation between the frequency of smoking and age. Older respondents used cigarettes more frequently than younger ones. In addition, positive connection was found between the frequency of smoking and perceptions of physical and psychological invulnerability as rated on the scales. Low correlation between psychological invulnerability and smoking was found. Physical invulnerability and smoking were only moderately related.

We also wanted to examine within the scope of the first research problem how these two aspects of invulnerability related to age, sex and satisfaction with specific life domains.

The correlation coefficients indicated in the Table 2 show higher perceptions of both physical and psychological invulnerability among older respondents. The sex variable was also highly related to both aspects of invulnerability. To check differences between sexes in perceptions of invulnerability, we have conducted two t-tests and found that significant differences were observed between boys and girls in terms of perceptions of physical $\left(t_{(295)}=8.247, p<.01\right)$ and psychological invulnerability $\left(t_{(295)}=5.360, p<.01\right)$. In that respect, boys perceived themselves as both physically and psychologically more invulnerable than girls.

Table 3. Perceptions of physical and psychological invulnerability in boys $(n=136)$ and girls $(n=161)$

\begin{tabular}{|c|c|c|c|c|}
\cline { 2 - 5 } \multicolumn{1}{c|}{} & \multicolumn{2}{c|}{ Physical invulnerability } & \multicolumn{2}{c|}{ Psychological invulnerability } \\
\cline { 2 - 5 } \multicolumn{1}{c|}{} & $\mathbf{M}$ & SD & 2.90 & SD \\
\hline Boys & 2.38 & 0.542 & 2.62 & 0.458 \\
\hline Girls & 1.91 & 0.445 & 0.449 \\
\hline
\end{tabular}

The next step was to compare how these two aspects of invulnerability related to life satisfaction among respondents - in general and in specific life domains. Positive correlation was found between psychological invulnerability and assessment of satisfaction with all seven life domains and general life satisfaction. Correlations ranged from low (satisfaction with community connectedness) to moderate (future security). In other words, assessment of satisfaction in all life domains was higher among respondents who thought they were more psychologically invulnerable. On the other hand, significant correlation was found between the sense of physical invulnerability and two domains of life - low negative correlation in case of satisfaction with health and low positive correlation in case of future security.

In terms of the second research problem, in order to examine how perceptions of physical and psychological invulnerability helped to explain different criterion variables - risky behavior (smoking) and life satisfaction - we carried out two hierarchical regression analyses. The first analysis included the frequency of smoking criterion (Table 4). Then, in the first step, we included demographic variables of age and sex. Sex turned out to be the only significant predictor of frequency of smoking. The second step of the analysis included physical and psychological invulnerability. Both 
variables accounted for the additional $20.4 \%$ of the variance. Unlike psychological invulnerability, physical invulnerability was statistically significant predictor of frequency of smoking. In the second step, sex (no statistical significance in the first step) became a statistically significant predictor. This may point to a potentially suppressor effect of the variable. The correlation between sex and physical invulnerability $(r=-.43)$ might have led to this effect.

Table 4. Results of hierarchical regression analysis with frequency of smoking as criterion variable and perceptions of physical and psychological invulnerability as predictors

\begin{tabular}{|c|c|c|}
\hline Predictors & $\mathbf{1}^{\text {st }}$ step & $\mathbf{2}^{\text {nd }}$ step \\
\hline Sex & -.018 & $.182^{\star *}$ \\
\hline Age & $.204^{\star *}$ & $.137^{\star}$ \\
\hline Physical invulnerability & & $.518^{\star *}$ \\
\hline Psychological invulnerability & & -.034 \\
\hline & .043 & .247 \\
\hline F & .043 & .204 \\
\hline
\end{tabular}

Notes: ${ }^{*} p<.05 ;{ }^{* *} p<.01$; sex: $1=$ boys, $2=$ girls

The objective of the second regression analysis was to examine how physical and psychological invulnerability contributed to general life satisfaction (Table 5).

Table 5. Results of hierarchical regression analysis with frequency of smoking as criterion variable and perceptions of physical and psychological invulnerability as predictors

\begin{tabular}{|c|c|c|}
\hline Predictors & step & step \\
\hline Sex & -.078 & -.074 \\
\hline Age & .043 & .031 \\
\hline Physical invulnerability & & $-.263^{* *}$ \\
\hline Psychological invulnerability & & $.404^{* *}$ \\
\hline & .009 & .152 \\
\hline F & .009 & .142 \\
\hline
\end{tabular}

Notes: ${ }^{* *} p<.01$; sex: $1=$ boys, 2 = girls

As the analysis demonstrates, both variables were significant predictors of life satisfaction whereby physical invulnerability represented a negative and psychological a positive (and higher) predictor. Both predictors accounted for $15 \%$ of variance of general life satisfaction. Since no significant correlation between physical invulnerability and life satisfaction was found, yet physical invulnerability emerged as a significant predictor, we have checked for potential suppression by excluding the psychological invulnerability predictor from the second step of the regression analysis. Physical invulnerability included in the second step of the regression analysis independently does not help to explain the criterion variable of life satisfaction, i.e. it is not a statistically significant predictor. On the basis of these findings, one can conclude that the significance of physical invulnerability in the regression analysis presented in the Table 5 may be ascribed to its moderate correlation with psychological invulnerability $(r=.42, p<.01)$. The conclusion of these analyses is that psychological invulnerability may help to explain life satisfaction criterion. This is not the case with physical invulnerability. 
Marija Milić, Ružica-Marija Vlajčić, Valerija Križanić: Perception of invulnerability, engaging in...

In order to check within the third research problem whether perceptions of physical and psychological invulnerability differed among respondents with different experience of engagement in health risk behaviors, respondents were divided into four groups on the basis of the selected statement about their experience of cigarette use: those that never tried smoking, those that tried smoking but did not smoke and those who smoked either occasionally or regularly.

As the Table 2 shows, significant correlation was found between sex and age and physical and psychological invulnerability, so, when checking the differences among students with different experiences in cigarette use in terms of their physical and psychological invulnerability, both the sex and age variable were considered as potential covariants. The analysis showed significant correlation between the sex covariant and physical invulnerability $\left(F_{(1,291)}=70.010, p<.01\right)$. On the other hand, the age covariant did not turn out to be significant $\left(F_{(1,291)}=1.891, p>.05\right)$. After controlling the effects of age and sex, respondents with different experience of cigarette use differed significantly in terms of their perceptions of physical invulnerability $\left(F_{(3,291)}=29.869, p<.01\right)$. If we analyse individual contribution of the experience of cigarette use variable to perception of physical invulnerability, it independently accounted for $23.5 \%$ of the variance (partial $\eta^{2}=.235$ ) of the result. The sex variance accounted for $19.4 \%$. The observed effects may be seen as significant since Cohen (1988) defined the effect size of 0.01 as small, 0.06 as medium and 0.14 and above as large. The Bonferroni post-hoc test found that perceptions of respondents who had never tried smoking were statistically significantly different from all other groups, i.e. compared to other groups, they had the lowest perceptions of physical invulnerability. Respondents who had tried smoking but didn't smoke and respondents who quit smoking did not show any differences in perceptions of physical invulnerability but both groups were different from the other groups. They perceived their physical invulnerability lower than smokers and higher than respondents who had never tried smoking. Smokers perceived themselves as physically more invulnerable than respondents who had never tried smoking and respondents who had tried smoking, yet they didn't smoke.

The Table 6 presents mean values of perceptions of invulnerability depending on the experience of cigarette use among survey respondents.

Table 6. Perceptions of physical and psychological invulnerability among respondents with different experience of cigarette use

\begin{tabular}{|c|c|c|c|c|c|c|}
\cline { 2 - 7 } \multicolumn{2}{c|}{} & N & M & SD & Minimum & Maximum \\
\hline \multirow{2}{*}{ Physical invulnerability } & Never tried smoking & 80 & 1.75 & 0.425 & 1.06 & 3.13 \\
\hline & Tried smoking but didn't smoke & 74 & 2.07 & 0.437 & 1.38 & 3.50 \\
\cline { 2 - 7 } & Quit smoking & 21 & 2.25 & 0.471 & 1.44 & 3.19 \\
\cline { 2 - 7 } & Smoked & 122 & 2.38 & 0.539 & 1.25 & 3.81 \\
\hline Psychological invulnerability & Never tried smoking & 80 & 2.62 & 0.494 & 1.62 & 3.69 \\
\hline & Tried smoking but didn't smoke & 74 & 2.76 & 0.438 & 1.38 & 3.62 \\
\cline { 2 - 7 } & Quit smoking & 21 & 2.88 & 0.437 & 2.23 & 3.77 \\
\cline { 2 - 7 } & Smoked & 122 & 2.81 & 0.474 & 1.77 & 4.00 \\
\hline
\end{tabular}

Unlike physical invulnerability, differences in psychological invulnerability among four groups of high school students with different experience of cigarette use, after checking the effects of sex and age, were not significant $\left(F_{(3,291)}=2.043, p>.05\right)$. 


\section{Discussion}

The objective of this paper was to examine two aspects of sense of invulnerability (physical and psychological) on a sample of high school students and the relationship between those two aspects and engagement in risky behaviors on the one hand and indicators of subjective wellbeing on the other.

The analyses found a positive correlation between the age and both aspects of invulnerability. The correlation is low but points to an increase in perception of invulnerability with age. These findings support the assumptions of the developmental approach to invulnerability according to which it increases during adolescence (Hill, Duggan and Lapsley, 2012). Earlier research has found that the sense of invulnerability rises between early and middle adolescence (Aalsma et al., 2006; Alberts et al., 2007). The findings in our research support the assumption of increase in perception of invulnerability during middle adolescence.

Analysis of differences in perceptions of invulnerability among boys and girls found that, compared to girls, boys considered themselves both physically and psychologically more invulnerable than girls. These finding support those of several existing studies (Aalsma et al., 2006; Alberts, Elkind and Ginsberg, 2007; Lapsley and Hill, 2010). One of the reasons behind these findings might lie in the way boys and girls socialize that may account for some significant differences in behavior and perceptions (of the sense invulnerability, among other feelings). According to Šikić Mićanović (1997), socialization helps young men to suppress feelings of pain, teaches them to be invulnerable and "tough" and develop autonomy and independence as soon as possible. The associated invulnerability may be connected to the fact that, compared to girls, boys are more prone to minor offences (Bennett, Farrington and Huesmann, 2000; Ručević, 2011), exhibit undesirable normative behavior (Ručević, 2011) and, generally, are more involved in delinquency than girls (Junger-Tas, Terlouw and Klein, 1994; Ručević, 2011).

Furthermore, in line with the initial hypothesis, the correlations obtained in this research point to differential relation between the two aspects of invulnerability (physical and psychological) with positive and negative outcomes among high school students. In concrete terms, perception of physical invulnerability shows moderate positive correlation with the amount of smoking but no correlation was found between this variable and any indicator of satisfaction in different life domains. This does not apply to the correlation between physical invulnerability and satisfaction with health and future security. On the other hand, very low correlation was found between perception of psychological invulnerability and smoking. Systematic positive correlation was found between psychological invulnerability and students' satisfaction with all selected life domains. These findings back the thesis that a sense of psychological invulnerability may be considered a potential psychological resource with a certain empowering function during adolescence. In that sense, an individual may be encouraged to engage in a number of new behaviors, potentially important for achieving psychosocial goals typical of adolescence (in terms of interpersonal relationships with parents, peers etc.). Successful achievement of goals that the individual finds important in a certain life domain will affect this aspect of subjective wellbeing (satisfaction with the associated life domain). Different patterns of correlation between physical and psychological invulnerability and a number of selected variables obtained through the survey support the approach that these two 
aspects of invulnerability represent two different constructs that might have different implications on individual's functioning.

The results of regression analysis including the frequency of smoking as the criterion also support the thesis that physical invulnerability may certainly help to explain the amount of smoking. It is interesting to note (as presented in the accompanying table) that psychological invulnerability does not contribute to explain this criterion. In other words, it does not significantly help to predict the frequency of this type of risky behavior. This goes hand in hand with the thesis that physical and psychological invulnerability represent two different constructs whereby one of them (physical invulnerability) serves as predictor of health risk behavior (smoking), unlike the other (psychological invulnerability that may not predict these negative outcomes).

The findings about contribution of these two aspects of invulnerability to assessment of general life satisfaction show that a sense of psychological invulnerability better predicts general life satisfaction in positive terms. Research conducted by Lapsley and Hill (2010) found similar patterns of behavior where the factor of psychological vulnerability emerged as a significant positive predictor of subjective wellbeing, unlike the factor of physical invulnerability. The pattern is consistent - psychological invulnerability represents a positive predictor of certain indicators of successful adjustment (measure of wellbeing). This is not the case with physical invulnerability.

Comparison of self-perceptions of invulnerability among high school students with qualitatively different experience of engagement in risky behaviors (cigarette use) found differences in a sense of physical invulnerability among selected groups of respondents. In line with the previous research, adolescents who smoked perceived themselves as physically more invulnerable than non-smokers (Arnett, 2000; Halpern-Felsher, Biehl, Kropp and Rubinstein, 2004). According to the assumptions, one may observe differences among high school students who reported different level of inclination to engage in this type of risky behavior. In the process, differences in perceptions of physical invulnerability among the groups were in line with the expected trend. Compared to the other three groups, non-smokers and those with no smoking experience reported lowest perceptions of physical invulnerability. The largest observed difference in perceptions was between them and respondents who smoked. In terms of ex-smokers and those who only tried smoking, the difference between non-smokers and those who never tried smoking and these two groups was less pronounced. Also, those who only tried smoking and those who never did reported different perceptions - respondents who did try smoking felt more physically invulnerable than those who didn't. Halpern-Felsher et al. (2004) had findings similar to these. The authors concluded that adolescents who smoked and those that had the intention to smoke held lower perceptions of smoking-related risks than never-smokers and those who didn't intend to smoke. This leads us to support the Frankenberger's (2004) thesis that adolescents who never wished to smoke developed different attitudes and perceptions of smoking compared to the "curious" ones who tried.

Ex-smokers emerged as a particularly interesting group. Their perceptions of physical invulnerability were not different from smokers' perceptions but they were different from those that never smoked. This backs the previous findings reported by Bright, Mckillop and Ryder (2008) that ex-smokers scored higher on invulnerability scale than individuals who never smoked. 
Based on this, we can conclude that individuals more engaged in risky behavior perceived themselves as more physically invulnerable. This can be interpreted in several ways. It seems unlikely that respondents who displayed risky behavior (i.e. smoking) were not aware of the associated risks. Viscuvi (1990) stated that not only people were familiar with smoking-related risks, but also overestimated the likelihood of contracting the associated diseases. These perceptions were even more pronounced among adolescents. Halpern-Felsher (2011) reported that numerous studies had confirmed the Viscuvi's findings (1990). The findings may be attributed to the difference between a subjective and objective perception of likelihood of contracting a disease. In other words, adolescent egocentrism might account for that. Although aware of the objective risk of smoking, young people are optimistic and underestimate their own risks of smoking-related diseases (Romer and Jamieson, 2001), i.e. smokers minimized the risk and tended to believe that they were less at risk than others (Weinstein, 1998). Romer and Jamieson (2001) reported that, although young people overestimated lung cancer risk, they underestimated the fatality of this disease. A sense of invulnerability may be associated to unrealistic risk assessment in terms of smoking addiction. Roditis, Lee and Halpern-Felsher (2015) stated that young people did not actually understand what addiction was, i.e. they often failed to recognize that addiction meant experiencing difficulty quitting and continuing to smoke longer than expected. These findings support the assumption of physical invulnerability that, the stronger the sense of physical invulnerability, the more convinced a person would be that he/she is resistant to addiction and that quitting would not represent a problem provided that he/she needs or wants to quit. In addition, according to Halpern - Felsher et al. (2004) and Slovic (1998), although generally aware of smoking-related health and long-term risks, young people are less conscious of the fact it causes addiction. Adolescent smokers are less worried about long-term effects of smoking because they believe that they can quit smoking easily and at any time (Arnett, 2000; Slovic, 1998).

In short, these findings support the idea that invulnerability includes different dimensions with different implications for positive and negative outcomes among adolescents.

\section{Limitations and guidelines for future studies}

As well as all other studies, this one also has several limitations. Firstly, any generalization of conclusions based on the study findings is limited by the sample size. Future studies should cover a larger sample of young people of adolescent age. Also, the recruited respondents came from the area of Slavonia. The majority of students (75.4\%) were inhabitants of Đakovo (i.e. a relatively small town). Since higher smoking prevalence is found in urban areas and prevalence of smoking rises with urbanization (Idris et al., 2007), the ratio and number of smokers, ex-smokers and non-smokers might have been different in larger towns. Furthermore, in terms of age, respondents were in middle or late adolescence so, in order to ensure more appropriate observation of trends when it came to invulnerability construct in future studies, young adolescents should also be recruited. If the function of development of psychological invulnerability is to help solve developmental challenges, one might question what happens to it after adolescence. Pronounced psychological invulnerability may ensure easier adjustment and resolution of developmental challenges, so Bjorklund and Green (1992) state that invulnerability may facilitate the taking of appropriate risks, motivate psychological separation from parents and provide inner resources to explore new ideas, roles and 
tasks. Yet, since each developmental stage is associated with particular developmental tasks, one might wonder what with invulnerability in solving developmental tasks in other developmental periods (e.g. career development, family formation etc.) and whether the perception of physical invulnerability was associated with some more serious behavioral difficulties in other age groups.

Limitations in terms of physical invulnerability and smoking primarily concern the sample size, especially because the focus was on comparison among groups of students who tried smoking, ex-smokers and smokers. If we divide the sample size into these sub-samples, we can conclude that they are relatively small so it imposes certain limitations to study conclusions. In addition, we never examined reasons for smoking initiation, quitting (in case of ex-smokers) or the age at which the respondents took on (or quit) smoking. These insights would have helped in better understanding of early smoking initiation and prevention, as well as its relationship to physical invulnerability.

One of the limitations to this study relates to the Invulnerability Scale (Ćorić et. al., 2018). This instrument was selected in the study to operationalize the invulnerability aspect given certain limitations of the adolescent invulnerability scale (AIS). For example, the AIS items were formulated in a rather general way (e.g. "Safety rules do not apply to me", "I'm a fragile person" or "Taking safety precautions is far more important to other people than it is for me") and this leaves room for differences in interpretation of questions among different respondents. The Invulnerability Scale (Ćorić et al., 2018) was created to improve the measurement of constructs by taking into account the stated limitations. Also, it was selected because it contains two subscales - physical and psychological invulnerability. The items include behaviors that cover relevant tasks of this developmental period or associated risky behaviors. In that respect, the most important ones include emotional independence from parents and other adults, development of own identity, values and beliefs, intimate connection and intimate relationship. The said scale also covers behaviors relevant for modern-day adolescents, such as online dating etc. The instrument's authors reported that the Invulnerability Scale accounted for $13.20 \%$ of the additional variance of risky behavior compared to its congruent AIS (according to Ćorić et al., 2019). Yet, since this is a relatively new instrument, additional checks of its psychometric characteristics are necessary since they haven't yet been explored to a sufficient degree.

Also, future studies might analyse potential mediation relation between the risk perception and perception of benefits of smoking in terms of personal invulnerability and smoking because it was observed that adolescent smokers perceived fewer smoking-related risks and more smoking-related benefits than non-smokers (Morrell, Lapsley and Halpern-Felsher, 2016). Moreover, in terms of the invulnerability construct, healthcare campaigns targeting increased invulnerability among adolescents are necessary, but the physical aspect of invulnerability should correctly be covered since it turned out to be a predictor of smoking and negative predictor of subjective wellbeing. On the other hand, psychological invulnerability should be employed and used as a psychosocial resource because the study has shown that it is a predictor of subjective wellbeing. Also, previous research found its negative correlation with depressive and interpersonal problems and problems with self-esteem (Aalsma, Lapsley and Flannery, 2006; Lapsley and Hill, 2010). Invulnerability is not a one-dimensional construct nor does it have one-dimensional consequences and implications for promotion of health. 
Risky behavior manifest in smoking is very much similar to some other forms of risky behaviors, such as alcohol consumption: in the short-run, it gives a sense of fulfilment, evokes symbols of adulthood (young people feel "grown up" while they smoke), parents prohibit it and, finally, it represents illegal substance to minors (Goldberg, Halpern-Felsher and Millstein, 2002). Yet, it would be good to examine whether the established relation between physical invulnerability and risky behavior applies to other types of such (risk-taking) behaviors.

As with the majority of studies of risky behavior and their predictors, the issue of prevention stands out as very important; i.e. how to implement the findings into the existing prevention programmes and how to modernize and improve them. The majority of youngsters who take on smoking know that smoking is harmful (as well as other risky behaviors). Despite this, early smoking initiation and smoking addiction among the youth still represent a problem. Insights into physical invulnerability of young smokers help to shed light upon this seemingly contradictory fact. Also, this study found that the youth inclined to take risks (who smoke) had stronger perception of physical invulnerability so the campaigns targeting young people and pointing to harmful effects of smoking by scaring them with adverse consequences might not bring about the desired results. This is in line with earlier research, e.g. study conducted by Siegel and Biener (2000). The study showed that media advertisements had effect only among younger adolescents (12-13-year old respondents), whereas it had no effect on older adolescents (aged 14 to 15 years). This should not come as a surprise if we take into consideration developmental tasks placed before young people of that age. Whereas, generally speaking, younger adolescents are more concerned with physical development and puberty (Byler et al., 1969, according to Millstein and Halpern-Felsher, 2002), middle adolescents are more concerned with physical appearance, interpersonal relationships with peers and members of the opposite sex (Millstein and Halpern-Felsher, 2002). In that respect, campaigns should target "younger" adolescents more prone to effects of anti-smoking campaigns, even more so because earlier studies showed that early positive experience with risky behavior increase the likelihood of other risky behaviors (Goldberg, Halpern-Felsher and Millstein, 2002) so the campaigns should focus on the youngest possible groups of adolescents. In addition, with respect of education, especially of younger adolescents, it is important to explain them the effects of smoking in a way that relates to them so that they could really understand, for example, what addiction meant and what implications it had.

Since the emphasis on adverse consequences has failed to produce the desire effects by experts and authors of preventive programs, the really question is what to do. Preventive programs should center on healthy environment (instead of focusing on harmful effects of smoking) and advantages of non-smoking since adolescent smokers reported decreased perceptions of risk and focused on benefits on smoking instead (Morell, Song, Halpern-Felsher, 2010). Emphasis should also be placed on factors that they find important in this life period, e.g. interpersonal relations with peers. This is supported by research findings (Morell, Song, Halpern-Felsher, 2010) according to which adolescents with more than six friends who smoked also reported increasing perceptions of benefits over time compared to adolescents with friends non-smokers, so it is expected that smoking initiation will begin sooner in their case. Furthermore, as the existing studies demonstrated, it is important to know that adolescents who reported higher perception of smoking-related benefits were more likely to take on smoking compared to others (Song et al., 2009). The perceived 
social benefit (looking cool, feeling relaxed, becoming popular and feeling grown-up) increase the likelihood of smoking (Aryal, Petzold and Krettek, 2013). This should be taken into consideration when creating anti-smoking campaigns, i.e. it is far more important to have an impact on young people's perception (perceived benefits) of smoking than focus on negative sides only since individuals tend to minimize them as their perception of physical invulnerability increases. Some authors (e.g. Goldberg et al., 2002) went that far to state that adolescents would engage in risky behaviors, although aware of the associate risk, because perceived benefits of such behavior outweighed perceived risks. When making assessments, adolescents might neglect the risk and overestimate the perception of benefit due to their sense of invulnerability. Future studies should thus examine perceptions of risks and benefits of smoking in relation to perceptions of physical invulnerability.

According to Halpern-Felsher (2011), very few studies compared susceptibility to risky behaviors of adults and adolescents. It would be good if future studies examined the relation of physical invulnerability and risky behavior, as well as potential subsequent changes in perception of physical invulnerability. Mahalik, Coley, Lombardi, Lynch, Markowitz and Jaffee (2013) reported that the prevalence of health risk behaviors steadily increased into the early 20 s and then levelled off or decreased. Regardless of all the campaigns and the growing evidence on harmful effects of smoking, in 2015, in Croatia, 31.1\% of people over 15 smoked (according to the CPHI, 2015). It would be interesting to know how a sense of physical invulnerability in adulthood differed among smokers and non-smokers. In that sense, it is still not known what happens with physical invulnerability in adults and how different it is among individuals who engage in risky behaviors (such as smoking) and those who don't.

\section{Conclusion}

The findings of the survey support the assumption that perceptions of physical and psychological invulnerability are associated, yet they represent different constructs. High school students with different experience of engagement in risky behaviors (smoking) have different perceptions of physical invulnerability - the perception is lowest among students who never smoked and highest among students smokers. Also, the study found that physical invulnerability helps to explain the amount of smoking whereas psychological invulnerability was not a statistically significant predictor of frequency of smoking. Unlike physical, psychological invulnerability is positively associated with satisfaction with all selected life domains and helps to explain the variance of general life satisfaction. In short, these findings support the thesis that invulnerability includes different dimensions with different implications for positive and negative outcomes among adolescents.

\section{Literature}

Aalsma, M., Lapsley, D.K., Flannery, D. (2006). Personal fables, narcissism, and adolescent adjustment. Psychology in the Schools. 43 (4), 481-491. doi: 10.1002/pits.20162

Alberts, A., Elkind, D., Ginsberg, S. (2007). The personal fable and risk-taking in early adolescence. Journal of Youth and Adolescence, 36, 71-76. doi: 10.1007/s10964-006-9144-4

Antaramian, S.P., Huebner, E.S., Valois, R.F. (2008). Adolescent life satisfaction. Applied Psychology: An International Review, 57(1), 112-126. doi: 10.1111/j.1464-0597.2008.00357.x 
Arnett, J. (1992). Reckless behavior in adolescence: A developmental perspective. Developmental review, 12(4), 339-373. doi: 10.1016/0273-2297(92)90013-R

Arnett, J.J. (2000). Optimistic bias in adolescent and adult smokers and nonsmokers. Addictive Behaviors, 25(4), 625-632. doi: 10.1016/S0306-4603(99)00072-6

Aryal, U.R., Petzold, M., Krettek, A. (2013). Perceived risks and benefits of cigarette smoking among Nepalese adolescents: a population-based cross-sectional study. BMC public health, 13, 187. Downloaded from: http://www.biomedcentral.com/1471-2458/13/187 (25. 10. 2019).

Bennett, S., Farrington, D.P., Huesmann, L.R. (2005). Explaining gender differences in crime and violence: The importance of social cognitive skills. Aggression and Violent Behavior, 10(3), 263-288. doi: 10.1016/j.avb.2004.07.001

Bjorklund, D.F., Green, B.L. (1992). The adaptive nature of cognitive immaturity. American Psychologist, 47(1), 46-54. doi: 10.1037/0003-066X.47.1.46

Bonilha, A.G., de Souza, E.S.T., Sicchieri, M.P., Achcar, J.A., Crippa, J.A.S., Baddini-Martinez, J. (2013). A motivational profile for smoking among adolescents. Journal of Addiction Medicine, 7(6), 439-446. doi: 10.1097/01.ADM.0000434987.76599.c0

Bright, S.J., Mckillop, D., Ryder, D. (2008). Cigarette smoking among young adults: Integrating adolescent cognitive egocentrism with the trans-theoretical model. Australian Journal of Psychology, 60(1), 18-25. doi: 10.1080/00049530701458043

Cohen, J. (1988). Statistical power analysis for the behavior sciences. Hillsdale, NJ: Erlbaum.

Cohn, L.D., Macfarlane, S., Yanez, C., Imai, W.K. (1995). Risk-perception: Differences between adolescents and adults. Health Psychology, 14(3), 217-222. doi: 10.1037/0278-6133.14.3.217

Ćorić, M., Vlajčić, R.M., Kolak, M., Goretić, I. (2018). Konstrukcija skale Osjećaja neranjivosti. Neobjavljene bilješke s kolegija Konstrukcija i interpretacija testova. Osijek: Filozofski fakultet.

Dečković Vukres, V., Uhernik, A.I., Mihel, S. (2015). Istraživanje o uporabi duhana u odrasloj populaciji Republike Hrvatske. Zagreb: Hrvatski zavod za javno zdravstvo (HZJZ). Downloaded from: https://www.hzjz.hr/wp-content/uploads/2016/02/Duhan_2015.pdf(25. 10. 2019)

Diener, E., Suh, E.M., Lucas, R.E., Smith, H.L. (1999). Subjective well-being: Three decades of progress. Psychological Bulletin, 125(2), 276-302. doi: 10.1037/0033-2909.125.2.276

Elkind, D. (1967). Egocentrism in Adolescence. Child Development, 38(4), 1025-1034. doi: $10.2307 / 1127100$

Ellickson, P.L., Tucker, J.S., Klein, D.J. (2001). High-risk behaviors associated with early smoking: results from a 5-year follow-up. The Journal of adolescent health, 28, 465-473. doi: 10.1016/S1054-139X(00)00202-0

Fidler, J.A., Wardle, J., Henning Brodersen, N., Jarvis, J.M., West, R. (2006). Vulnerability to smoking after trying a single cigarette can lie dormant for three years or more, Tobacco Control, 15(3), 205-206. doi: 10.1136/tc.2005.014894

Field, A. (2013). Discovering Statistics Using IBM SPSS, 4th Edition. London: Sage Publications.

Frankenberger, K.D. (2004). Adolescent Egocentrism, Risk Perceptions, and Sensation Seeking Among Smoking and Nonsmoking Youth. Journal of Adolescent Research, 19(5), 576-590. doi: 10.1177/0743558403260004

Gerrard, M., Gibbons, F.X., Benthin, A.C., Hessling, R.M. (1996). A longitudinal study of the reciprocal nature of risk behaviors and cognitions in adolescents: what you do shapes 
Marija Milić, Ružica-Marija Vlajčić, Valerija Križanić: Perception of invulnerability, engaging in...

what you think, and vice versa. Health Psychology, 15(5), 344-354. doi: 10.1037/02786133.15.5.344

Gilman, S.E., Rende, R., Boergers, J., Abrams, D.B., Buka, S.L., Clark, M.A. i dr. (2009). Parental smoking and adolescent smoking initiation: An intergenerational perspective on tobacco control. Pediatrics, 123(2), 274-281. doi: 10.1542/peds.2008-2251

Goldbeck, L., Schmitz, T., Besier, T., Herschbach, P., Henrich, G. (2007). Life satisfaction decreases during adolescence. Quality of Life Research, 16(6), 969-979. doi: 10.1007/s11136007-9205-5

Goldberg, J.H., Halpern-Felsher, B.L., Millstein, S.G. (2002). Beyond Invulnerability: The Importance of Benefits in Adolescents' Decision to Drink Alcohol. Health psychology, 21(5), 477484. doi: 10.1037/0278-6133.21.5.477

Good, G.E., Sherrod, N.B., Dillon, M.G. (2000). Masculine gender role stressor and men's health. In: R.M. Eisler i M. Hersen (edt.): Handbook of gender, culture and health (str. 63-81). New Jersey: Lawrence Erlbaum Associates.

Halpern-Felsher, B.L. (2011). Adolescent Decision-Making. U: B.B. Brown i M. Prinstein (ur.), Encyclopedia of Adolescence, 1rt Vol. (str. 30-37). San Diego: Academic Press.

Halpern-Felsher, B.L., Biehl, M., Kropp, R., Rubinstein, M. (2004). Perceived risks and benefits of smoking: Differences among adolescents with different smoking experiences and intentions. Preventive Medicine, 39(3), 559-567. doi: 10.1016/j.ypmed.2004.02.017

Haranin, E., Huebner, E.S., Suldo, S.M. (2007). Predictive and incremental validity of global and domain-based adolescent life satisfaction reports. Journal of Psychoeducational Assessment, 25(2), 127-138. doi: 10.1177/0734282906295620

Hawkins, W.E., Hawkins, M.J., Seeley, J. (1992). Stress, health-related behavior and quality of life on depressive symptomatology in a sample of adolescents. Psychological Reports, 71(1), 183-186. doi: 10.2466/pro.1992.71.1.183

Hill, P.L., Duggan, P.M., Lapsley, D. (2012). Subjective Invulnerability, Risk Behavior, and Adjustment in Early Adolescence. The Journal of Early Adolescence, 32(4), 489-501. doi: $10.1177 / 0272431611400304$

Huebner E. (2004). Research on assessment of life satisfaction of children and adolescents. Social Indicators Research, 66(1/2), 3-33. doi: 10.1023/B:SOCI.0000007497.57754.e3

Idris, B.I., Giskes, K., Borrell, C., Benach, J., Costa, G., Federico, B., Helakorpi, S. i sur. (2007). Higher smoking prevalence in urban compared to non-urban areas: time trends in six European countries. Health \& Place, 13(3), 702-712. doi: 10.1016/j.healthplace.2006.11.001.

Junger-Tas, J., Terlouw, G.J., Klein, M.W. (1994). Delinquent behavior among young people in the western world. Amsterdam, NL: Kugler Publications.

Kalebić Maglica, B., Martinac Dorčić, T. (2015). Osobine ličnosti i socijalni faktori kao odrednice konzumacije cigareta i alkohola kod adolescenata. Društvena istraživanja, 24(2), 197217. doi: $10.5559 /$ di.24.2.02

Kaliterna Lipovčan, Lj., Prizmić Larsen, Z., Brkljačić, Z. (2011). Međunarodni indeks dobrobiti - podaci za Hrvatsku. In: G. Vuletić (edt.): Kvaliteta života i zdravlja (41-51). Osijek: Filozofski fakultet Sveučilišta u Osijeku.

Khosravi, A., Mohammadpoorasl, A., Naieni, K., Mahmoodi, M., Pouyan, A.A., Mansournia, M.A. (2016). Causal Effect of Self-esteem on Cigarette Smoking Stages in Adolescents: 
Coarsened Exact Matching in a Longitudinal Study. Osong Public Health and Research Perspectives, 7(6), 341-345. doi: 10.1016/j.phrp.2016.10.003

Koivumaa-Honkanen, H., Honkanen, R., Koskenvuo, M., Viinamäki, H., Kaprio, J. (2002). Life dissatisfaction as a predictor of fatal injury in a 20-year follow-up. Acta Psychiatrica Scandinavia, 105(6), 444-450. doi: 10.1034/j.1600-0447.2002.01287.x

Koivumaa-Honkanen, H., Honkanen, R., Viinamäki, H., Heikkilä, K., Kaprio, J., Koskenvuo, M. (2001). Life satisfaction and suicide: A 20-year follow-up study. The American Journal of Psychiatry, 158(3), 433-439. doi: 10.1176/appi.ajp.158.3.433

Kovčo Vukadin, I., Novak, M., Križan, H. (2016). Zadovoljstvo životom: individualna i obiteljska perspektiva. Kriminologija i socijalna integracija, 24(1), 84-115. doi: 10.31299/ksi.24.1.4

Kriesi, I., Buchmann, M. (2012). Educational success and adolescents' well-being in Switzerland. Swiss Journal of Sociology, 38(2), 245-265. doi: 10.5167/uzh-68739

Krosnick, J.A., Chang, L., Sherman, S.J., Chassin, L., Presson, C. (2006). The effects of beliefs about the health consequences of cigarette smoking on smoking onset. Journal of Communication, 56(1), 18-37. doi: 10.1111/j.1460-2466.2006.00281.x

Lapsley, D. (2003). The two faces of adolescent invulnerability. In: D. Romer (edt.), Reducing adolescent risk: Toward an integrated approach (str. 25-31). Newbury Park, CA: Sage. doi: 10.4135/9781452233611.n4

Lapsley, D.K., FitzGerald, D., Rice, K., Jackson, S. (1989). Separation-individuation and the "new look" at adolescent egocentrism: A test of an integrative model. Journal of Adolescent Research, 32(4), 483-505. doi: 10.1177/0272431611400304

Lapsley, D.K., Hill, P.L. (2010). Subjective Invulnerability, Optimism Bias and Adjustment in Emerging Adulthood. Journal of Youth Adolescence, 39, 847-857. doi: 10.1007/s10964-009-9409-9

Mahalik, J.R., Coley, R.L., Lombardi, C.M., Lynch, A.D., Markowitz, A.J., Jaffee, S.R. (2013). Changes in health risk behaviors for males and females from early adolescence through early adulthood. Health Psychology, 32(6), 685-694. doi: 10.1037/a0031658

Martin, K.M., Huebner, E.S., Valois, R.F. (2008). Does life satisfaction predict adolescent victimization? Psychology in the Schools, 45(8), 419-431. doi: 10.1002/pits.20336

Millstein, S.G., Halpern-Felsher, B. (2002). Perceptions of Risk and Vulnerability. Journal of Adolescent Health, 31(1), 10-27. doi: 10.1016/S1054-139X(02)00412-3

Morrell, H.E., Lapsley, D.K., Halpern-Felsher, B.L. (2016). Subjective invulnerability and perceptions of tobacco-related benefits predict adolescent smoking behavior. Journal of Early Adolescence, 36(5), 679-703. doi: 10.1177/0272431615578274

Morrell, H.E., Song, A.V., Halpern-Felsher, B.L. (2010). Predicting adolescent perceptions of the risks and benefits of cigarette smoking: A longitudinal investigation. Health Psychology, 26(6), 610-617. doi: 10.1037/a0021237

Newcomb, M.D., Bentler, P.M., Collins, C. (1986). Alcohol use and dissatisfaction with self and life: A longitudinal analysis of young adults. Journal of Drug Issues, 16(4), 479-494. doi: $10.1177 / 002204268601600401$

Nolen-Hoeksema, S., Rusting, C.L. (1999). Gender differences in well-being. In: D. Kahnema, E. Diener i N. Schwartz (edt.): Well-being: The foundations of hedonic psychology (str. 330-352). New York: Russell Sage Foundation. 
Marija Milić, Ružica-Marija Vlajčić, Valerija Križanić: Perception of invulnerability, engaging in...

O'Loughlin, J.O., Karp, I., Koulis, T., Paradis, G., DiFranza, J. (2009). Determinants of first puff and daily cigarette smoking in adolescents. American Journal of Epidemiology, 170(5), 585-597. doi: 10.1093/aje/kwp179

Ottová-Jordan V., Smith O.R., Gobina I., Mazur J., Augustine L., Cavallo F. i dr. (2015). Trends in multiple recurrent health complaints in 15-year-olds in 35 countries in Europe, North America and Israel from 1994 to 2010. European Journal of Public Health, 25(2), 24-27. doi: 10.1093/eurpub/ckv015

Park, H.S., Koo, H.Y., Schepp, K.G. (2005). Predictors of suicidal ideation for adolescents by gender. Taehan Kanho Hakhoe Chi, 35(8), 1433-1442. doi: 10.4040/jkan.2005.35.8.1433

Pejnović Franelić, I., Markelić, M., Muslić, Lj., Musić Milanović, S., Pavić Šimetin, I., Mayer, D. i dr. (2016). Europsko istraživanje o pušenju, pijenju i uzimanju droga među učenicima ES$P A D$, Zagreb: Hrvatski zavod za javno zdravstvo (HZJZ). Downloaded from: https:// www.hzjz.hr/wp-content/uploads/2016/10/HR_ESPAD_2015_RGB_3.pdf (25. 10. 2019).

Räikkönen, E., Kokko, K., Chen, M., Pulkkinen, L. (2012). Patterns of adult roles, their antecedents and psychosocial wellbeing correlates among Finns born in 1959. Longitudinal and Life Course Studies, 3 (2), 211-227. doi: 10.14301/llcs.v3i2.180

Roditis, M., Lee, J., Halpern-Felsher, B.L. (2016). Adolescent (Mis)Perceptions About Nicotine Addiction: Results From a Mixed-Methods Study. Health education \& behavior, 43(2), 156-164. doi: 10.1177/1090198115598985

Rodriguez, D., Romer, D., Audrain-McGovern, J. (2007). Beliefs about the risks of smoking mediate the relationship between exposure to smoking and smoking. Psychosomatic Medicine, 69(1), 106-113. doi: 10.1111/j.1460-2466.2006.00281.x

Romer, D., Jamieson, P. (2001). Do adolescents appreciate the risks of smoking? Evidence from a national survey. Journal of Adolescent Health, 29(1), 12-21. doi: 10.1016/S1054139X(01)00209-9

Roothman, B., Kirsten, D., Wissing, M. (2003). Gender differences in aspects of psychological well-being. South African Journal of Psychology, 33(4), 212-218. doi: 10.1177/008124630303300403

Ručević, S. (2011). Povezanost privrženosti roditeljima s rizičnim i delinkventnim ponašanjem kod adolescenata. Društvena istraživanja, 20(1), 167-187. doi: 10.5559/di.20.1.09

Salmela-Aro, K., Ek, E., Taanila, A., Chen, M. (2012). Role configurations in young adulthood, antecedents, and later well-being among Finns born in 1966. Longitudinal and Life Course Studies, 3(2), 228-242. doi: 10.14301/llcs.v3i2.184

Sarason, I.G., Mankowski, E.S., Peterson, A.V., Dinh, K.T. (1992). Adolescents' reasons for smoking. Journal of School Health, 62(5), 185-190. doi: 10.1111/j.1746-1561.1992.tb06039.x

Schoon, I., Martin, P., Ross, A. (2007). Career transitions in times of social change. His and her story. Journal of Vocational Behavior, 70(1), 78-96. doi: https://doi.org/10.1016/j. jvb.2006.04.009

Schulenberg, J.E., Bryant, A.L., O'Malley, P.M. (2004). Taking hold of some kind of life: How developmental tasks relate to trajectories of well-being during the transition to adulthood. Development and Psychopathology, 16(4), 1119-1140. doi:10.1017/S0954579404040167

Siegel, M., Biener, L. (2000). The Impact of an Anti smoking Media Campaign on Progression to Established Smoking: Results of a Longitudinal Youth Study. American Journal of Public Health, 90(3), 380-386. doi: 10.2105/ajph.90.3.380 
Slovic, P. (1998). Do adolescent smokers know the risks? Duke Law Journal, 47(6), 1133-1141. doi: $10.2307 / 1373033$

Song, A.V., Morrell, H.E.R., Cornell, J.L., Ramos, M.E., Biehl, M., Kropp, R.Y., Halpern-Felsher, B. L. (2009). Perceptions of smoking-related risks and benefits as predictors of adolescent smoking initiation. American Journal of Public Health, 99(3), 487-492. doi: 10.2105/ AJPH.2008.137679

Steinberg, I. (2008). A Social Neuroscience Perspective on Adolescent Risk-Taking. Developmental review, 28(1), 78-106. doi: 10.1016/j.dr.2007.08.002

Suldo, S.M., Huebner, E.S. (2004). Does life satisfaction moderate the effects of stressful life events on psychopathological behavior during adolescence? School Psychology Quarterly, 19(2), 93-105. doi: 10.1521/scpq. 19.2.93.33313

Šikić-Mićanović, L. (1997). Socialization and gender: the significance of socio cultural contexts. Društvena istraživanja, 6(4-5), 577-595.

Taylor, S.E., Gollwitzer, P.M. (1995). Effect of mindset on positive illusions. Journal of Personality and Social Psychology, 69(2), 213-226. doi: 10.1037//0022-3514.69.2.213

Trimpop, R.M. (1994). What Are the Consequences of Risk Taking Behavior? U Trimpop, R. M. (ur.), The Psychology of Risk Taking Behavior Advances in Psychology (181-210). Amsterdam, NL: Elsevier doi: 10.1016/s0166-4115(08)61301-1

U.S. Department of Health and Human Services (USDHHS), Centers for Disease Control and Prevention, National Center for Chronic Disease Prevention and Health Promotion, Office on Smoking and Health. (2014). The health consequences of smoking-50 years of progress. A report of the surgeon general. Downloaded from: https://www.ncbi.nlm. nih.gov/pubmed/24455788 (20.11.2019.).

Veenhoven, R. (2000). The Four Qualities of Life Ordering Concepts and Measures of the Good Life. Journal of Happiness Studies, 1(1), 1-39. doi: 10.1007/978-94-007-5702-8_11

Viscusi, W.K. (1990). Do smokers underestimate risks? Journal of Political Economy, 98(6), 12531269. doi: $10.1086 / 261733$

Weinstein, N.D. (1998). Accuracy of smokers' risk perceptions. Annals of Behavioral Medicine, 20(2), 135- 140. doi: 10.1080/14622299050011721

Weinstein, N.D., Klein, W.M. (1996). Unrealistic optimism: present and future. Journal of Social and Clinical Psychology, 15(1), 1-8. doi: 10.1521/jscp.1996.15.1.1

World Health Organization (WHO). Regional Office for Europe. (2016) $\mathrm{D}$. Growing up unequal: gender and socioeconomic differences in young people's health and well-being. World Health Organization. Regional Office for Europe. Downloaded from: https://apps.who.int/iris/ handle/10665/326320 (20. 11. 2019).

Zloković, J., Vrcelj, S. (2010). Rizična ponašanja djece i mladih. Odgojne znanosti, 12(1), 197-213.

Zullig, K.J., Valois, R.F., Huebner, E.S., Oeltmann, J.E., Drane, J.W. (2001). Relationship between perceived life satisfaction and adolescents' substance abuse. Journal of Adolescent Health, 29(4), 279-288. doi: 10.1016/S1054-139X(01)00269-5 
Marija Milić

Odsjek za psihologiju, Filozofski fakultet, Sveučilište Josipa Jurja Strossmayera u Osijeku

Ružica-Marija Vlajčić

Valerija Križanić

Odsjek za psihologiju, Filozofski fakultet, Sveučilište Josipa Jurja Strossmayera u Osijeku

\title{
Percepcija neranjivosti, upuštanje u rizična ponašanja i zadovoljstvo životom kod srednjoškolaca
}

\begin{abstract}
Sažetak
Osjećaj neranjivosti često se povezuje isključivo s rizičnim ponašanjem adolescenata. No, prema nekim razvojnim teorijama, ona je također i adaptivan odgovor na razvojne zadatke koji se javljaju u tom periodu života. Cilj ovoga rada bio je istražiti dva aspekta osjećaja neranjivosti (fizičke i psihološke) na uzorku srednjoškolaca. Preciznije, istražen je odnos fizičke i psihološke neranjivosti s upuštanjem u rizična ponašanja (konzumacijom cigareta) s jedne strane te pokazateljima subjektivne dobrobiti (zadovoljstvo životom) s druge strane. $U$ radu su analizirani podatci 297 sudionika dobi od 16 do 20 godina ( $M=17,33$; $\mathrm{SD}=0,834 ; 54,2 \%$ djevojaka). Istraživanjem je utvrđeno kako su se mladići procjenjivali kao fizički i psihološki neranjiviji od djevojaka. Adolescenti koji puše procjenjivali su svoju fizičku neranjivost većom od adolescenata koji su prestali pušiti, koji su samo probali pušiti i onih koji nisu nikada pušili. Dok fizička neranjivost nije povezana s procjenama na većini domena zadovoljstva životom, psihološka je pozitivno povezana sa svim domenama kao i s općim zadovoljstvo životom. Utvrđeni rezultati također pokazuju kako procjena psihološke neranjivosti u većoj mjeri doprinosi objašnjenju zadovoljstva životom od procjene fizičke neranjivosti, dok je fizička neranjivost značajan prediktor čestine pušenja adolescenata. Rezultati ovog istraživanja upućuju na značaj i važnost obje domene neranjivosti u razdoblju adolescencije.
\end{abstract}

Ključne riječi: adolescenti, fizička i psihološka neranjivost, pušenje, zadovoljstvo životom 